\title{
STRATEGI INOVASI DAN RENCANA IMPLEMENTASI UNTUK MENDORONG SDM UNGGUL DI MASA PANDEMI
}

\author{
Meddy Nurpratama ${ }^{1 *}$, Agus Yudianto ${ }^{2}$ \\ Fakultas Ekonomi Universitas Wiralodra Indramayu, Indonesia ${ }^{1,2}$ \\ Email: nurpratamameddy@gmail.com ${ }^{1 *}$, agusyudianto556@yahoo.com ${ }^{2}$
}

\begin{tabular}{|c|c|}
\hline Artikel info & \\
\hline Artikel history & Abstrak \\
\hline Diterima : 25-12-2020 & Penelitian ini bertujuan untuk mengetahui strategi inovasi apa saja dalam upaya \\
\hline Direvisi : 10-01-2021 & membangun SDM yang unggul di masa Pandemi Covid-19. Mengetahui rencana \\
\hline Disetujui : 19-01-2021 & $\begin{array}{l}\text { 1mplementasi strateg1 dalam upaya membangun SDM yang unggul di masa } \\
\text { Pandemi Covid-19. Metode dalam artikel ini menggunakan metode deskriptif }\end{array}$ \\
\hline & $\begin{array}{l}\text { yaitu dengan menjelaskan semua teori dan konseptual yang ada dengan } \\
\text { mengumpulkan seluruh informasi berdsarakan mengetahui strategi inovasi apa } \\
\text { saja dalam upaya membangun SDM yang unggul di masa Pandemi Covid-19. }\end{array}$ \\
\hline $\begin{array}{l}\text { Kata Kunci: strategi inovasi; } \\
\text { rencana implemetasi; sumber } \\
\text { daya manusia unggul }\end{array}$ & $\begin{array}{l}\text { Hasil mengetahui strategi inovasi apa saja dalam upaya membangun SDM yang } \\
\text { unggul di masa Pandemi Covid-19. Mengingat pentingnya peran SDM bagi } \\
\text { sebuah organisasi atau perusahaan, maka dalam kondisi Pandemi Covid-19 ini } \\
\text { pun mereka tetap perlu untuk meningkatkan kualitas dan dapat unggul dalam } \\
\text { berbagai kondisi serta situasi yang sulit dikendalikan. Beberapa strategi patut } \\
\text { dilakukan sebagai upaya dalam rangka mendorong SDM tersebut agar tetap } \\
\text { unggul serta produktif. }\end{array}$ \\
\hline
\end{tabular}

Keywords: innovation

Abstract

strategy; implementation plan; This study aims to find out what innovation strategies

excellent human resources are in an effort to build superior human resources during the Covid-19 Pandemic. Know the strategy implementation plan in an effort to build superior human resources during the Covid-

19 Pandemic. The method in this article uses a descriptive method, namely by explaining all existing theories and conceptuals by collecting all information based on knowing what innovation strategies are in an effort to build superior human resources during the Covid-19 Pandemic. The results of knowing what innovation strategies are in an effort to build superior human resources during the Covid-19 Pandemic. Given the important role of HR for an organization or company, even in the conditions of the Covid-19 Pandemic they still need to improve quality and be able to excel in various conditions and situations that are difficult to control. Several strategies should be implemented as an effort to encourage human resources to remain superior and productive.

Korespondence author: Meddy Nurpratama

Email: nurpratamameddy@ gmail.com artikel dengan akses terbuka dibawah lisensi 


\section{Pendahuluan}

Sumber daya manusia sebagai sumber keunggulan bersaing harus mendukung organisasinya dengan kemauan dan kemampuan mempelajari sesuatu yang baru, toleransi terhadap ambiguitas, relationship skill, feksibel, inovatif, mobile, dan berpendidikan (Smale et al., 2019). Sumber daya manusia merupakan aset penting yang diperlukan perusahaan dalam rangka mendukung implementasi strategis bisnis yang efektif. Sumber daya manusia yang berkualitas, unggul, dan terlatih merupakan aspek penting bagi perusahaan dalam mempertahankan daya saing dan keunggulan kompetitif dibandingkan kompetitor. Manusia yang berkualitas dan unggul akan menciptakan value bagi organisasi yang baik, serta mampu memanfaatkan teknologi dengan tepat guna. Manusia bertalenta harus berkelimpahan dalam hal mind-set, heart-set, dan skill-set. Manusia yang cerdas, bekerja dengan ikhlas, dan tangkas dalam melakukan tugasnya dalam suatu organisasi atau bisnis (Shopiana, 2020).

SDM yang unggul juga harus dibangun dengan matang dan kokoh terutama dalam menghadapi situasi buruk yang dapat mempengaruhi perkembangan sebuah organisasi atau perusahaan. Kondisi emosional yang tidak didukung penuh, sekaligus minimnya kesadaran pimpinan terhadap pentingnya memperhatikan kebutuhan elemen selama pandemi covid-19 ini, justru akan mendorong kondisi perusahaan atau organisasi yang semakin melemah (Santika, 2020).

Sebagaimana dikemukakan (Mindarti et al., 2020) bahwa salah satu strategi untuk dapat mempercepat pemulihan pembangunan pasca pandemi Covid-19 adalah melalui pemanfaatan industri 4.0 yang dapat dioptimalkan untuk memberdayakan potensi SDM yang unggul dan berdasaing, sebagai modal dasar untuk mendorong pembangunan daerah secara lebih nyata dan berkelanjutan.

Namun demikian, dengan memperhatikan masih adanya kesenjangan kapasitas SDM dalam menerapkan revolusi industri 4.0 yang berbasis penerapan digitalisasi dalam kerangka pembangunan nasional, maka upaya untuk memulihkan perekonomian terdampak Covid-19 masih menghadapi kendalayang perlu diatasi melalui penerapan instrument Sistem Manajemen Nasional yang berbasis prinsip penterpaduan faktor karsa sarana upaya (ends means ways), dalam mengkonversi potensi yang dimiliki SDM untuk menjadi kemampuan nyata untuk dapat memulihkan kondisi pembangunan nasional yang terpuruk akibat pandemi Covid 19 (Makmur \& Hadi, 2020).

Tujuan dari penelitian ini untuk mengetahui strategi inovasi apa saja dalam upaya membangun SDM yang unggul di masa Pandemi Covid-19. Mengetahui rencana implementasi strategi dalam upaya membangun SDM yang unggul di masa Pandemi Covid-

19. Manfaat mampu memberi pemahaman mengenai strategi inovasi dalam membangun SDM yang unggul di masa Pandemi. Memberi gambaran rencana implementasi terhadap strategi tersebut.

\section{Meddy Nurpratama dan Agus Yudianto}

\section{Metode Penelitian}

Metode dalam artikel ini menggunakan metode deskriptif yaitu dengan menjelaskan semua teori dan konseptual yang ada dengan mengumpulkan seluruh informasi berdsarakan mengetahui strategi inovasi apa saja dalam upaya membangun SDM yang unggul di masa Pandemi Covid-19 (Mustari \& Rahman, 2012). Hasil mengetahui strategi inovasi apa saja dalam upaya membangun SDM yang unggul di masa Pandemi Covid-19. Kemudian disusun menjadi kesimpulan dan rekomendasi.. 


\section{Hasil dan Pembahasan}

\section{A. Strategi Inovasi}

Perlunya sebuah strategi dalam mendorong Sumber Daya Manusia (SDM) yang mampu unggul di tengah masa pandemi covid-19, maka berdasarkan hasil pemikiran penyusun, diperkuat dengan beberapa referensi sumber, beberapa strategi inovasi yang dapat dilakukan diantaranya yaitu sebagai berikut :

\section{Desain Ulang Pekerjaan (Job Redesign)}

Pada masa Pandemi Covid-19 saat ini banyak perusahaan ataupun organisasi yang terkena dampak salah satunya dengan memberlakukan kebijakan work from home. Berlakunya kebijakan tersebut menuntut perusahaan atau sebuah organisasi untuk mengubah desain pekerjaan yang dilakukan sebelum terjadinya wabah virus tersebut.

Desain pekerjaan (job design) adalah suatu proses untuk mengorganisasi pekerjaan ke suatu penugasan yang dibutuhkan untuk menunjang suatu pekerjaan tertentu (Gomez-Mejia et al., 2010). Selain itu desain pekerjaan juga dapat diartikan sebagai cara untuk memotivasi dan memberikan tantangan kepada karyawan agar lebih produktif dengan menentukan spesifikasi tugas dan metode penugasannya. Mengubah desain pekerjaan selama masa Pandemi Covid-19 ini menjadi cara yang efektif karena dapat mengurangi kejenuhan karyawan dalam bekerja di rumah, mengurangi tekanan dan stress pada diri karyawan, serta dapat meningkatkan kepuasan kerja karyawan. Desain pekerjaan memiliki pengaruh penting di antaranya pada alur pekerjaan, strategi bisnis dan struktur organisasi (Gomez-Mejia et al., 2010). Penerapan desain pekerjaan yang paling tepat selama masa Pandemi Covid-19 ialah menyesuaikan alur pekerjaan agar tetap dapat memantau kinerja karyawannya yang bekerja di rumah. Desain pekerjaan ini bisa disesuaikan dengan kapasitas sekaligus sesuai dengan jenis pekerjaan yang ada di organisasi atau perusahaan tersebut yang mana juga disesuaikan dengan sistem kerja pada saat pandemi covid-19. Misalnya, dengan adanya PSBB sehingga dilakukan work from home, maka untuk jenis pekerjaan tertentu yang mana biasanya dilakukan secara langsung bisa di desain ulang dengan sistem dan informasi yang dibutuhkan oleh SDM yang bersangkutan, sehingga SDM mampu beradaptasi terkait dengan kondisi pekerjaan di tengah krisis ataupun kejadian yang tidak terduga.

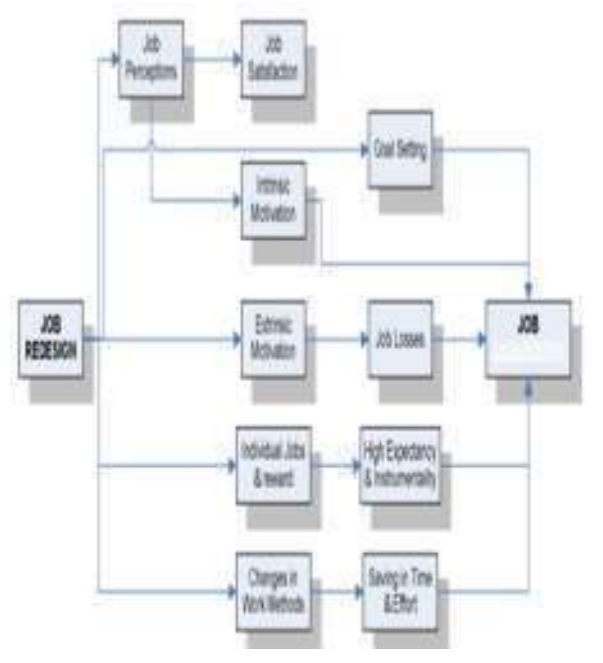


Gambar I. Job Redesign dengan Kelly's Twin-Track Mode

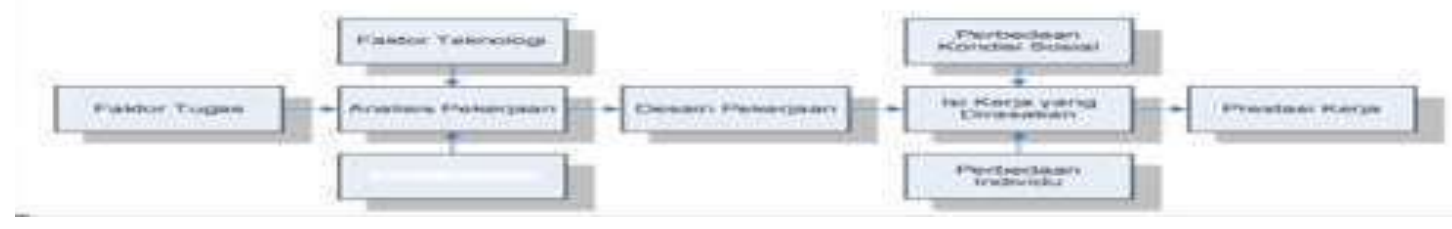

Gambar II. Model Konseptual Desain Pekerjaan dan Prestasi Kerja

Model diatas menunjukkan empat mekanisme dimana suatu desain ulang pekerjaan memungkinkan terjadi peningkatan kinerja, yaitu:

1. Pekerja menegoisasikan perubahan dalam isi pekerjaan sebagai pertukaran atas kenaikan pendapatan, menuju suatu persetujuan dimana dapat bekerja dengan suatu pekerjaan yang serupa, tetapi dengan penghasilan individu yang lebih tinggi (menjelaskan arti bekerja keras, bekerja dengan intensif).

2. Perlu dilakukan perbaikan pada kinerja karena pekerja merasa ada hubungan yang dekat antara usaha, kinerja, dan penghargaan yang diterima (dijelaskan dengan teori ekspektasi).

3. Desain ulang pekerjaan meningkatkan penetapan tujuan, dan penetapan tujuan ini adalah untuk memotivasi kinerja yang lebih baik.

4. Desain ulang pekerjaan melakukan perbaikan efisiensi dari metode bekerja, dan hal ini menuju pada perbaikan kinerja, tanpa perubahan apapun dalam motivasi pekerja.

Dengan mempertimbangkan faktor-faktor dalam model Twin-Track diatas diharapkan peningkatan kinerja dapat diwujudkan dengan langkah nyata demi pencapaian prestasi kerja.

2. Pengembangan Pengetahuan SDM melalui Pelatihan Virtual atau Online

Di samping itu, salah satu sarana untuk mencapai produktivitas karyawan serta SDM yang unggul juga melalui perancangan program pelatihan bagi karyawan. Seperti yang diungkap oleh (Colombo \& Stanca, 2008), bahwa pelatihan sebagai alat utama dan kuat untuk berhasil mencapai tujuan organisasi dan meningkatkan produktivitas karyawan. Selain itu menurut Menurut (Appiah, 2010), bahwa program pelatihan yang dirancang untuk memberikan manfaat yang lebih besar bagi karyawan dan organisasi itu sendiri, dengan melalui berbagi pengetahuan, keterampilan, dan kompetensi dapat meningkatan produktivitas karyawan.

Pada saat virus corona (covid19) menyebar di Indonesia serta menyebabkan banyak manusia yang tertular, maka pemerintah mencanangkan program Pembatasan Sosial Berskala Besar (PSBB) yang salah satu program yang dijalankan perusahaan adalah mengadakan kegiatan bekerja dari rumah atau work from home (wfh). Meskipun perusahaan menerapkan wfh bagi para karyawannya, akan tetapi program pelatihan karyawan harus tetap berjalan dalam rangka menjaga daya saing perusahaan. Daya saing sendiri menurut Peraturan Menteri Pendidikan Nasional No. 41 Tahun 2007 tentang standar proses dalam (Sudaryo et al., 2018) mendefinisikan daya saing adalah kemampuan untuk menunjukkan hasil yang lebih baik, lebih cepat atau lebih bermakna. Kemampuan yang dimaksud adalah (1) kemampuan memperkokoh pangsa pasarnya, (2) kemampuan menghubungkan dengan lingkungannya, (3) kemampuan meningkatkan kinerja tanpa henti, (4) kemampuan menegakkan posisi yang menguntungkan.

Pelatihan dapat dilakukan dengan mengembangkan individu dalam bentuk peningkatan keterampilan, pengetahuan dan sikap. Pelatihan tidak hanya berguna untuk karyawan, tapi juga perusahaan. Dimana, perusahaan tidak akan berkembang jika 
karyawannya tidak memiliki keterampilan dan minat kerja yang tinggi. Melalui pelatihan inilah, perusahaan dapat menggali potensi karyawannya dengan mengembangkan keterampilan yang mereka miliki. Dengan begitu, setiap perusahaan yang menerapkan pelatihan pada karyawannya akan menghasilkan SDM yang unggul dan berkualitas (Purnaya \& SE, 2016).

Adapun program yang dijalankan berupa program pelatihan jarak jauh (daring). Agar proses belajar lebih interaktif, penyelenggaraan pelatihan dilakukan melalui metode video- based training dengan menggunakan fasilitas video dalam proses belajar di ruangan kelas serta fasilitas video conference untuk proses pembelajaran jarak jauh.

Di dalam menjalankan program pelatihan bagi perusahaan, salah satu kunci utama dari sisi pelaksanaan adalah kontinyu dan dinamis. Walau perusahaan dihadapkan pada dampak covid 19, produktivitas perusahaan harus digenjot, jangan menunggu produktivitas perusahaan digenjot setelah pandemi berakhir.

Menurut (Prabawa \& Supartha, 2018) bahwa pelatihan dapat memungkinkan karyawan untuk memaksimalkan tingkat produktivitas. Kemudian (Rabbani et al., 2007) juga menjelaskan bahwa setelah mengumpulkan bukti pendukung dan menganalisa data yang relevan, ditemukan bahwa peningkatan produktivitas bergantung kepada pelaksanaan pelatihan yang sesuai. Meskipun pandemi virus corona terus melanda Indonesia, sehingga membuat kita - hidup bersamall dengan virus corona, produktivitas dan tingkat keunggulan karyawan harus tetap dijaga melalui program pelatihan yang kontinyu untuk tetap menjaga daya saing dan keunggulan kompetitif perusahaan.

3. Pendayagunaan dan Pemanfaatan Teknologi (Digitalization) di Masa Pandemi bagi SDM

Kemajuan teknologi menjadikan para SDM untuk mampu memperluas kemampuannya di bidang teknologi. Karyawan yang cakap dengan memanfaatkan kemajuan teknologi akan berdampak baik bagi perusahaan di era sekarang. Pada dasarnya teknologi merupakan alat bantu untuk menjadikan pekerjaan menjadi mudah yang dampaknya sangat efsien dan efektif bagi organisasi.

Pelatihan dalam pemanfaatan kemajuan teknologi ditargetkan untuk pegawai yang baru maupun pegawai yang lama. Hal ini penting untuk membawa perusahaan beradaptasi dengan realitas zaman.

Contoh kemanfaatan perubahan kemajuan teknologi adalah pada saat kejadian Pandemi Covid-19 menuntut para karyawan dan seluruh SDM untuk cakap dalam memanfaatkan kemajuan teknologi. Kemajuan teknologi akhirnya menunjukkan diri sebagai inovasi terbaik manusia untuk menghadapi pandemi.

Peran teknologi yang penting di tengah pandemi covid-19 ini, maka juga harus diikuti dengan strategi dari tiap SDMnya untuk dapat mengambil peluang dan memanfaatkan momen tersebut untuk pengembangan skill dan meningkatkan keunggulan mereka. Di samping memanfaatkan teknologi di era digital ini untuk sarana komunikasi antar SDM atau divisi di sebuah organisasi atau perusahaan, teknologi juga dapat dijadikan sebagai sarana yang dapat membantu mengoptimalkan dan mengefisiensi pekerjaan-pekerjaan yang membutuhkan kemampuan akan hal tersebut, terutama beberapa pekerjaan yang sudah di desain ulang untuk dilakukan secara online atau work from home (wfh). Skill teknologi bisa diasah oleh setiap SDM baik itu melalui program pelatihan khusus, maupun melalui webinar untuk meningkatkan pengetahuan dan upgrading skill yang memang sangat dibutuhkan untuk meningkatkan kualitas dari Sumber Daya Manusia yang ada (Rustam, n.d.) 


\begin{tabular}{|c|c|}
\hline DESAIN ULANG \\
PEKERJAAN
\end{tabular}$\rightarrow \rightarrow \begin{gathered}\text { PELATIHAN } \\
\text { ONLINE/VIRTUAL } \\
\text { (DIGITALIZATION) }\end{gathered}$

Keunggulan pada diri setiap Sumber Daya Manusia yang ada dalam sebuah organisasi terutama di tengah kondisi Pandemi Covid-19 juga tak luput di dorong dari faktor yang memang sangat langsung mempengaruhi dari diri orang tersebut. Penguatan dari dalam diri juga sangat penting sebagai kapasitas untuk bertahan dan berkembang di tengah kondisi yang tidak diharapkan diantaranya yaitu memperhatikan komponen Iman, Imun, dan Aman. Ketiga hal yang juga turut menjadi pondasi utama yang disosialisasikan oleh pemerintah kepada setiap elemen sumber daya manusia yang ada. Berikut penjabaran strategi inovasi untuk mendorong kualitas SDM dan meningkatkan produktivitas melalui faktor internal tersebut

\section{Iman}

Mentoring sebagai suatu pendekatan dalam mengembangkan minat pekerja yang menjadi bagian penting untuk menciptakan perusahaan/organisasi yang lebih siap bersaing dalam kemajuan dan persaingan usaha. Dalam mentoring akan menciptakan suatu hubungan intrapersonal yang merupakan bentuk rasa kepedulian dan dukungan antara seorang yang memiliki pengalaman dan pengetahuan luas dengan seseorang yang dirasa masih kurang dalam hal pengetahuan dan pengalamannya. Hal tersebut sangatlah bermanfaat apabila diaplikasikan kepada karyawan-karyawan suatau perusahaan selama masa pandemi covid19 ini. Seseorang karyawan dalam suatu perusahaan yang mana memiliki pengetahuan dan pengalaman yang lebih luas misalkan seorang manajer atau kepala bagian bisa menjadikan dirinya menjadi seorang mentor untuk memberikan dukungan, kepedulian dan berbagi pengetahuan serta pengalamannya kepada seorang karyawan yang menjadi bawahan di struktur organisasi tersebut. Sehingga karyawan yang belum memiliki banyak pengalaman dan pengetahuan tersebut akan menjadikan dukungan dan kepedulian atasannya sebagai semangat dan motivasi dalam bekerja di masa pandemi saat ini. Sehingga kegiatan mentoring tersebut nantinya akan menciptakan suatu hubungan yang unik antar pribadi dan terjadi hubungan kemitraan pembelajaran. Antara mentoring satu karyawan dengan yang lainnya tidak ada suatu kesamaan, hal ini disebabkan karena masing-masing individu memiliki pola interaksi khusus dan berbeda satu dengan yang lainnya. Mentoring yang dapat diterapkan pada suatu organisasi / perusahaan salah satunya yaitu spiritul mentoring.

Spiritual mentoring merupakan suatu pendekatan aktivitas mentoring yang lebih menekankan pada penguatan spiritual yang dimiliki pekerja sehingga akan lebih semangat dalam melaksanakan pekerjaannya. Spiritual mentoring menjadi suatu hubungan yang memang disengaja untuk lebih fokus pada spiritualitas yang menjadikan Allah SWT sebagai tujuan dan investasi berdasarkan pada pengalaman hidup orang lain.

Spiritual di tempat kerja dapat diartikan sebagai upaya yang dilakukan individu atau pegawai dalam mengahayati nilai-nlai yang terdapat pada dirinya sendiri secara penuh 
ketika mereka melakukan kegiatan di tempat kerja.

Spiritualitas memiliki sifat prakultural, lebih primer dibandingakan dengan agama serta memberikan nilai-nilai yang mudah dipahami dan dapat digunakan sebagai pedoman, contonya yaitu nilai kejujuran dan integritas (Rahmasari, 2012). Nilai kejujuran dan integritas menjadi nilai terpenting yang harus dimiliki oleh setiap pegawai suatu perusahaan. Spiritual mentoring ini menjadi hal terpenting yang perlu diterapkan suatu perusahaan untuk menjaga semangat kerja yang dimiliki pekerja selama di masa Pandemi Covid-19 ini.

Fitrahnya seorang manusia sebagai makhluk spiritual telah memiliki kecerdasan spiritual masing-masing yang mana hal tersebut digunakan untuk menganut dan menjalankan sistem keagamaan. Organisasi atau perusahaan selama masa Pandemi Covid19 ini dapat melakukan pengelolaan spiritual yang dimiliki oleh pegawai dengan memfasilitasinya dalam hal mentoring. Sehingga, walaupun pegawai dalam masa pandemi ini melakukan work from home tetapi mereka tetap menghayati dan menggunakan nilainilai secara penuh yang terdapat pada dirinya khusunya yaitu kejujuran dan integritas dalam melakukan pekerjaannya sama seperti ketika mereka bekerja di kantor / tempat kerjanya.

Konsep spiritual mentoring dapat dilakukan pengukuran dengan beberapa hal sebagai berikut:

1. Pendampingan untuk semangat kerja

Bagi perusahaan yang menerapkan kebijakan work from home pada situasi pandemi seperti saat ini sangat diperlukan adanya mentoring yang khususnya berkaitan dengan memberikan kepedulian kepada pegawainya dalam bentuk penyemangatan dalam bekerja. Kejenuhan pasti dapat terjadi pada pegawai yang mana sebelum terjadinya wabah ini mereka dapat bersosialisasi dengan rekan kerjanya tetapi setelah adanya wabah ini sosialisasi mereka terbatas melalui telepon, pesan singkat maupun sosial media lainnya

Jika hal tersebut tetap dibiarkan tanpa adanya kepedulian yang intens dari rekan kerja dan khususnya atasan maka dapat terjadi penurunan semangat kerja. Penurunan semangat kerja ini akan berdampak pada segala aspek pekerjaan terutama pada target penyelesaian tugas yang menjadi kewajiban pegawai tersebut. Oleh karena itu, pemberian dukungan dan kepedulian dengan memberikan semangat kerja dari atasan kepada pegawainya dapat menambah semangat kerja mereka, sehingga akan meminimalisasi kejenuhan dalam bekerja selama masa Pandemi Covid-19 ini.

2. Pendampingan untuk peningkatan produktivitas kerja

Selain pendampingan untuk memberikan semangat kerja bagi pegawai, diperlukan juga suatu organisasi melakukan pendampingan untuk peningkatan produktivitas kerja pegawainya. Hal tersebut sangat bermanfaat ketika di aplikasikan pada masa pandemi saat ini. Pendampingan untuk peningkatan produktivitas kerja ini sebagai cara perusahaan dalam mengelola, mengatur dan memantau kegiatan para pegawainya selama work from home, sehingga para pegawai tetap dapat menyelesaikan tugas dari pekerjaannya dengan tepat waktu. Hal ini bukan berarti perusahaan hanya memberikan beban tugas saja untuk diselesaikan pegawainya, akan tetapi perusahaan juga memberikan cara pemecahan masalah, solusi, masukan dan pendapat lainnya sehingga dapat lebih mengefektifkan produktivitas kerja dan membantu meringankan beban tugas yang diberikan kepada pegawainya. Keberhasilan suatu organisasi / perusahaan dalam memberikan mentoring 
(pendampingan) untuk semangat kerja para pegawainya juga akan berdampak positif pada peningkatan produktivitas kerja pegawai.

3. Pendampingan untuk peningkatan prestasi kerja

Masa Pandemi Covid-19 ini bukan menjadi suatu alasan dan penghalang bagi pegawai untuk tidak mencapai suatu prestasi kerja. Hal ini bisa menjadi perhatian bagi perusahaan untuk menciptakan suatu program pendampingan untuk peningkatan prestasi kerja pegawainya. Keberhasilan suatu organisasi / perusahaan dalam mentoring peningkatan produktivitas kerja pegawainya akan berdampak positif juga terhadap pencapaian prestasi kerja dari pegawainya. Selain itu untuk menarik para pegawai dalam meningkatkan prestasi kerja di masa pandemi ini dapat dilakukan dengan memberikan reward bagi pegawai yang memiliki kinerja baik selama pandemi dan penerapan punishment ketika pegawai tersebut tidak dapat menyelesaikan tugas dengan baik. Hal tersebut dapat menjadi sebuah motivasi bagi pegawai untuk tetap produktiv dan semangat selama work from home, sehingga dapat mencapai prestasi kerja. Bagi pegawai yang belum bisa mencapai prestasi kerja dapat diberikan pendampingan secara khusus seperti pengarahan dan memberikan solusi agar mereka juga tetap semangat untuk menjadi lebih baik lagi.

4. Pendampingan untuk peningkatan spiritual dalam bekerja.

Spiritualitas menjadi salah satu faktor yang diperlukan di tempat kerja. Seorang pegawai yang memiliki spiritualitas mereka akan menghayati nilai-nilai yang dimilikinya secara penuh dalam melaksanakan pekerjaannya. Hal tersebut sangat diperlukan pada masa pandemi saat ini. Suatu perusahaan yang menerapkan kebijakan work from home juga diperlukan monitoring khususnya dalam peningkatan spiritual bekerja. Kebijakan work from home juga memberikan dampak negatif bagi pegawai salah satunya yaitu dapat menurunkan semangat dalam bekerja karena mereka merasa jenuh setiap harinya di rumah untuk mengerjakan pekerjaan kantor. Oleh karena itu sangat diperlukan monitoring untuk peningkatan spiritual dalam bekerja bagi pegawai yang melakukan work from home.

Dalam memberikan pendampingan spiritual ini, para manajer atau kepala bagian dapat memonitor dan memberikan dukungan motivasi ekstrinsik sehingga pegawai akan senantiasa dengan senang hati melakukan pekerjaannya tanpa menjadikannya sebuah beban. Spiritual mentoring menjadi suatu yang memiliki keunggulan ketika proses mentoring tersebut fokus pada satu hal yaitu spiritual. Fokus pada spiritual ini lebih ke arah bagaimana membentuk dan menumbuhkan spiritualitas pada pegawai. Pembentukan dan pertumbuhan spiritualitas ini akan mencakup pada unsur-unsur seperti kedisiplinan dan tantangan. Disiplin menjadi unsur pertama dalam fokus spiritual karena untuk memastikan perilaku yang tepat dalam mentoring. Selain itu kedisplinan untuk mengukur kedalam spiritual seseorang seperti disiplin saat menjalan ibadah. Seseorang yang memiliki kedisiplinan secara spiritual maka dalam bekerja pun juga akan menerapkan hal yang sama. Unsur yang kedua dalam fokus spiritual ialah tantangan yang menjadi dasar pada konteks spiritual mentoring. Tantangan dalam hal ini ketika seseorang mendapatkan suatu tugas baru dalam pekerjaannya dan tidak menjadikan hal tersebut sebagai beban, akan tetapi terus mencari cara penyelesaian dengan bantuan pembimbingan dari mentor. Sehingga tantangan tersebut menjadikan sebuah transformasi bagi pegawai agar lebih siap menghadapi perubahanperubahan dimasa mendatang. Hal tersebut diperlukan ditengah Pandemi Covid-19 saat ini 
sehingga spiritualitas dari pegawai tetap tumbuh lebih baik serta lebih siap menerima tantangan-tantangan baru.

\section{Imun}

Bagi karyawan yang baru melakukan pekerjaan jarak jauh, tentu menjadi sebuah tantangan tersendiri. Selain sistem kerja yang mengharuskan karyawannya bekerja di dalam rumah, secara psikologi karyawan pasti juga cukup terganggu. Karyawan semakin lama akan merasa stres bila selalu bekerja, selain pekerjaan yang menumpuk juga karyawan kesulitan dalam melakukan interaksi secara langsung yang biasa dilakukan sebelumnya. Untuk itu, manajer bisa melakukannya dengan pendekatan yang lebih intens. Pendekatannya bisa dilakukan panggilan telpon maupun online. Seperti misalnya, manajer bisa menanyakan secara langsung kepada karyawan bagaimana kondisinya sekarang. Setelah itu manajer bisa menanyakan secara perlahan bagaimana pencapaian kerjanya selama pergantian sistem kerja. Selanjutnya manajer bisa meminta kritik \& saran kepada karyawan. Hal ini berguna dalam membangun semangat kerja para karyawannya serta meningkatkan produktivitas dan keunggulan SDM.

Selain itu dengan rutin berkomunikasi antar manajer dengan karyawan akan meningkatkan semangat karyawannya. Ini bisa menjadi sebagai bentuk dukungan moral karena ditengah-tengah Pandemi Covid-19 ini, terlebih bagi SDM atau karyawan yang work from home, hanya akan berkutat di lingkungan rumah saja. Dan itu bisa membuat karyawan rentan merasa tertekan yang bila dibiarkan begitu saja akan mengganggu psikologi karyawannya

\section{Aman}

Membuat kebijakan tantang jaminan alat perlindungan kesehatan dengan memberi masker, hand sanitizer, dan penyemprotan disinfektan di seluruh area perusahaan atau organisasi sebagai pencegahan penyebaran covid-19 dan untuk menjamin kesehatan serta kenyamanan para karyawan dalam bekerja. Dengan adanya alat perlindungan kesehatan dapat mengantisipasi kecemasan karyawan atau SDM akibat virus Corona. Kesehatan menjadi aset yang paling penting di tengah wabah covid-19 saat ini.

Perusahaan dapat memberikan pemeriksaan secara gratis seperti tes kesehatan dengan cara bekerja sama dengan suatu lembaga kesehatan. Dengan langkah ini diharapkan mampu mengetahui kondisi kesehatan karyawan dan mengantisipasi penularan virus Covid19. Secara tidak langsung hal ini memberikan suatu kepuasan terhadap karyawan sehingga suasana hati dan emosional mereka lebih terkondisikan. Pemberian nutrisi untuk karyawan Nutrisi merupakan kebutuhan yang penting dalam situasi wabah COVID-19 saat ini untuk menambah imunitas tubuh agar tidak mudah terserang oleh virus. Sebagai contoh nutrisi yaitu telur, madu, susu, dan vitamin yang dapat diberikan perusahaan terhadap para karyawan agar terjamin kesejahteraannya di sektor pemenuhan kebutuhan nutrisi tubuh.

Selanjutnya, Sumber Daya Manusia yang mampu unggul di tengah situasi pandemi pun juga tak luput dari dorongan strategi melalui pemberian motivasi dari para pimpinan atau atasannya. Motivasi di tengah PSBB terhadap elemen SDM yang ada di dalam sebuah organisasi atau perusahaan dapat dilakukan dengan strategi atau cara-cara yang inovatif. Seperti dalam teori MARS Model, disebutkan bahwa motivasi menjadi salah satu unsur atau 
aspek yang juga dapat mempengaruhi kinerja dan perilaku seorang karyawan atau SDM yang ada di sebuah organisasi atau perusahaan. Motivation (Motivasi) berkaitan dengan kekuatan pada diri seseorang yang mempengaruhi arah, keinginan, dan persistensinya dalam mengerjakan perilaku tertentu. Karena memiliki arah, maka motivasi tidak bersifat acak alias memiliki tertentu. Juga terkait dengan seberapa besar intensitas dorongan itu dapat membawa seseorang ke perilaku yang dibutuhkan. Kemudian, selain itu ada persoalan berapa lama (persistensi) seseorang menjalankan perilakunya hingga sampai ke tujuannya.

Dengan adanya pemberian motivasi secara berkelanjutan terutama dalam kondisi yang memang sangat dibutuhkannya dorongan yang kuat untuk tetap bertahan dan meningkatkan kualitas bagi para SDM, maka dengan adanya motivasi tersebut menjadi strategi pembangun hasrat melakukan pekerjaan atau kegiatan dengan kecenderungan untuk dapat meraih sasaran dengan energi dan keteguhan atau terciptanya rasa optimisme. Maka dalam hal ini, pemberian semangat atau motivasi kepada SDM di tengah masa pandemi covid-19 dapat dilakukan melalui :

\section{Sharing Session atau Sesi Diskusi}

Intensitas pertemuan tatap muka di tengah situasi yang tidak memungkinkan, yakni dengan adanya PSBB, maka pertemuan dapat diganti dengan melalui digitalisasi yakni sesi diskusi melalui virtual atau secara daring. Di tengah pembangunan SDM yang harus tetap unggul, maka sharing session akan sangat berpengaruh dan penting bagi diri setiap SDM nya. Pimpinan dapat terus mengontrol secara berkala dan berkelanjutan mengenai produktivitas dan kinerja dari para karyawannya dan mengetahui pula hal-hal yang sekiranya terjadi dan menjadi problem yang dapat dijadikan sebagai bahan diskusi menarik untuk meningkatkan sikap kritis sekaligus menjadi sarana dalam meningkatkan hubungan antar Sumber Daya Manusia yang ada di dalam suatu organisasi atau perusahaan tersebut. Sharing session dapat dilakukan minimalnya satu minggu sekali, di mana pembahasan dilakukan setiap departemen atau divisi. Dalam hal ini untuk meningkatkan keunggulan SDM juga maka pimpinan harus mampu memberi motivasi-motivasi yang membangun semangat kinerja. Sharing Session juga bisa bersifat lebih hangat kepada seluruh elemen SDM sehingga kenyamanan dalam menyampaikan setiap pendapat atau gagasan bisa dirasakan.

Kegiatan ini juga dapat disambung dengan melakukan berbagai games attractive lainnya yang membangun pola pikir dan kebersamaan SDM.

\section{Penciptaan Virtual Team Building}

Team Building merupakan proses yang terjadi dari aktivitas formal yang ditujukan untuk meningkatkan pengembangan dan berfungsinya kerja tim. Intervensi dibutuhkan jika karyawan sudah turnover atau kehilangan fokus, terlebih di bawah tekanan kondisi atau situasi yang sulit diprediksi seperti masa Pandemi Covid-19 ini. Intervensi bisa dalam bentuk mengklarifikasi lagi tujuan kinerja tim, meningkatkan motivasi untuk mencapai sasaran, dan menjalankan mekanisme untuk memberikan feedback secara sistematik pada kinerja tim. Juga meningkatkan kemampuan pemecahan masalah tim. Terus juga, mengklarifikasi dan merekonstruksi persepsi anggota atas peran mereka dan harapan peran anggota ke anggota lain. Role-definition juga membantu pengembangan model mental yang dianut-representasi common internal seseorang atas situasi di luarnya, seperti bagaimana 
berinteraksi dengan klien, me-maintain mesin dan terlibat di rapat. Team building yang sering dilakukan adalah meningkatkan hubungan antar-anggota tim. Aktivitas membantu saling belajar. Para karyawan atau SDM di dalamnya dengan sengaja membangun mekanisme di mana mereka saling berbagi, membangun pengetahuan. Bentuk lain adalah membangun rasa saling percaya dan berusaha mengelola konflik. Di masa Pandemi seperti sekarang ini, melakukan virtual tema building menjadi sebuah kebutuhan dan strategi yang tidak luput ditinggalkan. Terlebih dibantu dengan adanya kecanggihan teknologi yang memungkinkan seluruh SDM untuk tetap terhubung kapan pun dan di mana pun.

Beberapa diantaranya yaitu seperti :

1. Sering melakukan video chat

2. Menciptakan live-remote office

3. Online messaging

4. Struktur rapat

5. Menerapkan umpan balik

\section{B. Rencana Implementasi}

Berdasarkan strategi inovasi yang telah dijabarkan di atas dalam rangka mendorong Sumber Daya Manusia (SDM) yang mampu unggul di masa Pandemi Covid-19 ini, adapun rencana pengimplementasian atas strategi tersebut yaitu sebagai berikut :

1. Melakukan Desain Ulang Pekerjaan (Job Redesign)

Dalam implementasinya, ada beberapa tahapan yang akan dilakukan terkait proses penerapan desain ulang pekerjaan (Job Redesign) yaitu sebagai berikut :

a. Persiapan awal

Ada dua hal yang harus dipersiapkan dalam hal ini, yaitu identifikasi pekerjaaan dan penyusunan daftar pertanyaan. Proses identifikasi pekerjaan tergantung besar kecilnya perusahaan. Dalam perusahaan kecil proses indentifikasinya lebih sederhana dibandingkan dengan perusahaan yang besar, sebab dalam perusahaan besar identifikasi pekerjaan dapat disusun atas dasar bagan organisasi, catatan-catatan pembayaran upah, penyelia dan lain sebagainya. Tahap selanjutnya adalah pemutusan tentang informasi yang diperoleh agar memberikan hasil yang berguna, untuk itu perlu disusun daftar pertanyaan yang isinya mencakup status dan identifikasi pekerjaan, fungsi, tugas, tanggung jawab, karakteristik dan kondisi pekerjaan serta standar prestasi kerja lainnya.

b. Pengumpulan Data

Sebagai tindak lanjut dari analisis pekerjaan. Ada lima teknik cara pengumpulan data, yaitu:

1) Observant.

Yaitu pengamatan langsung terhadap subyek yang akan diamati (karyawan) selamamelaksanakan tugas. Kelemahan yang didapat yaitu memakan biaya banyak, lambat dan kurang akurat. Adapun kebaikannya yaitu memungkinkan analis mendapatkan informasi tangan pertama, memungkink ananalisis untuk mengenal kondisi kerja, ketrampilan dan peralatan yang akan digunakan. 
2) Wawancara.

Dengan mewancarai karyawan baik yang menempati posisi karyawan maupun atasan langsung, sehingga dapat memeriksa kebenaran tanggapan yang diterima. Hal ini digunakan untuk mencari ketepatan informasi.

3) Kuesioner

Pendekatan ini memungkinkan banyak pekerjaan dapat di pelajari secara bérsamaan dan dengan biaya murah.

4) Logs.

Orang yang menduduki posisi diminta untuk memberikan informasi. Logs ini terdiri dari catatan yang di simpan karyawan pelaksana. Logs ini hampir sama dengan kuesioner. Kelemahan dari logs yaitu tidak menunjukkan data-data penting seperti kondisi kerja, peralatan yang digunakan, lingkungan dan sebagainya.

5) Kombinasi

Yaitu gabungan dari seluruh metode di atas untuk memperoleh data yang Qualified dan dapat dipercaya kebenarannya.

c. Penyempurnaan Data

Dari data yang diperoleh lalu dipisah -pisahkan untuk memperoleh data yang relevan, yang untuk selanjutnya siap digunakan dalam berbagai bentuk seperti diskripsi pekerjaan, spesifikasi pekerjaan dan standar-standar pekerjaan.

1) Diskripsi Pekerjaan (Job Description).

Yaitu pernyataan tertulis tentang fungsi, tugas, tanggung jawab, wewenang, kondisi kerja dan aspek - aspek pekerjaan lainnya. Dalam suatu diskripsi pekerjaan, bagian identitas jabatan bisa mencakup kode pekerjaan, bagian departemen, tanggal penyusunan dan kelas pekerjaan, setelah itu dilanjutkan kebagian peringkasan pekerjaan atau fungsi. Bagian ini menunjukkan apa pekerjaan yang dilakukan, bagaimana dan mengapa hal itu dikerjakan, yang selanjutnya dijabarkan dalam tugas-tugas pekerjaan". Dalam diskripsi jabatan juga harus diperinci tentang wewenang dan tanggung jawab pekerjaan secara terpisah, siap yang menjadi atasan dan siapa bawahannya serta lingkungan phisik pekerjaan.

2) Spesifikasi Pekerjaan (Job Spesification).

Menunjukkan siapa yang melakukan pekerjaan itu dan faktor — faktor manusia yang disyaratkan, antara lain pendidikan, ketrampilan, latihan, pengalaman, serta persyaratan fisik.

Spefikasi pekerjaan adalah pembagian kerja berdasarkan keahlian dan spesialisasi keahlian yang dimiliki oleh pekerja dalam suatu organisasi tertentu. Dalam pengerjaan suatu produk misalnya pengerjaan mobil di pabrik Toyota terdapat berbagai divisi seperti divisi perakitan, pengecatan, pemotongan dan sebagainya. Pembagian kerja dalam produksi mobil oleh pabrik Toyota tersebut tentunya demi mempermudah proses pengerjaan produk tersebut. Jadi adanya spesifikasi bertujuan untuk memudahkan pekerjaan dalam suatu organisasi yang sesuai dengan keahlian sumber daya manusia yang dimiliki organisasi tersebut. 
3) Standar Prestasi Kerja (Job Performance Standards)

Dasar untuk meniliai prestasi kerja karyawan, ini memberikan dua manfaat:

1. Target pelaksanaan kerja

2. Kriteria keberhasilan kerja.

d. Teknik Pelaksanaan

Beberapa teknik pelaksanaan dihadirkan dengan mengikuti atau menyesuaikan berdasarkan kondisi dan situasi dunia saat ini yang tengah menghadapi tantangan pandemi covid-19. Sistem kerja yang dirancang kembali dengan prosedur yang tepat. Berikut teknik dalam melakukan job redesign :

1. Rotasi pekerjaan (job rotation) adalah praktik untuk menggerakkan individu dari pekerjaan ke pekerjaan guna mengurangi kebosanan dan meningkatkan motivasi potensial dan prestasi. Praktik ini melibatkan rotasi manajer dan non manajer dari satu pekerjaan ke pekerjaan lainnya. Dengan demikian individu diharapkan untuk menyelesaikan lebih banyak aktifitas pekerjaan. Karena setiap pekerjaan terdiri tugas-tugas yang berbeda. Rotasi pekerjaan melibatkan peningkatan rentang pekerjaan dan persepsi atas ragam isi pekerjaan. Peningkatan keragaman tugas berkaitan dengan studi terbaru, akan meningkatkan kepuasan karyawan, mengurangi beban mental, menurunkan jumlah kesalahan karena faktor kelelahan, meningkatkan produksi dan efisiensi, dan mengurangi kecelakaan kerja (Kim et al., 2014).

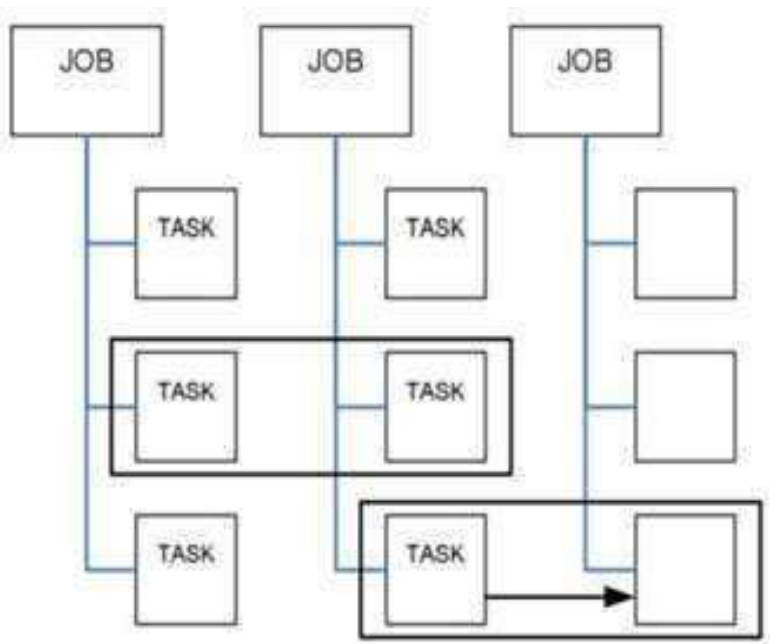

Gambar IV. Pengaturan Aliran Tugas dalam Job Rotation 
2. Pemerkayaan pekerjaan (job enrichment) adalah praktik peningkatan keleluasaan individu (wewenang) sehingga bisa menyeleksi aktifitas dan hasil. Peningkatan kedalaman pekerjaan akan memacu setiap individu untuk berpretasi dan karena itu mengisi kebutuhan pertumbuhan dan otonomi. Proses ini dapat digambarkan seperti gambar berikut ini (Kim et al., 2014).

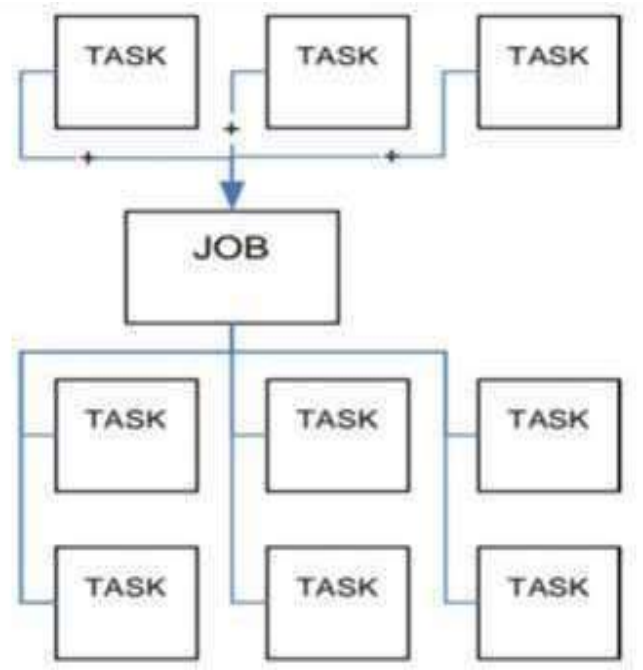

Gambar V. Pemerkayaan Tugas dalam Job Enrichment

e) Monitoring

Langkah akhir yaitu dengan melakukan monitoring terhadap hasil dari adanya perubahan terhadap design ulang pekerjaan dalam suatu organisasi atau perusahaan yang erat kaitannya dengan pengaruh terhadap produktivitas dan kenyamanan kerja seluruh SDM yang bersangkutan, sehingga hasilnya dapat menjadi bahan pertimbangan dalam melakukan job redesign di masa yang akan datang atau ketika dihadapkan pada situasi atau kondisi yang tidak diharapkan seperti masa pandemi ini. SDM diharuskan pula dapat mudah beradaptasi dan mampu lebih berinovasi dan berpikir lebih kritis..

2. Pelatihan Online atau E-Training

Dalam implementasinya, ada beberapa tahapan yang akan dilakukan terkait proses penerapan pelatihan atau training secara virtual dengan beberapa model yaitu sebagai berikut:

1) Melakukan Pelatihan Berdasarkan Pemanfaatan Media Website

a) Melakukan Analisis Kebutuhan Program

Sebelum melakukan atau mengadakan sebuah pelatihan atau training secara online untuk pengembangan pengetahuan dan keterampilan Sumber Daya Manusia di dalam sebuah organisasi atau perusahaan, maka langkah paling awal ialah dengan menganalisis apa saja yang menjadi kebutuhan yang perlu untuk diserap dari hasil pelatihan setelahnya. Keterkaitan kebutuhan yang telah dianalisis tersebut nantinya akan mempengaruhi jenis atau model penerapan dari pelatihan atau training online yang akan dilaksanakan sekaligus mencari sumber informan atau trainer yang tepat dan sesuai, sehingga efektivitas dan efisiensi terjadi.

b) Perancangan Website 
Setelah melakukan tahap analisis peneliti melanjutkan ke tahap perancangan (design). Untuk menggambarkan kebutuhan fungsional yang diharapkan dari website yang akan dirancang maka peneliti membuat use-case diagram. Use-case diagram adalah gambaran graphical dari beberapa atau semua actor, use-case dan interaksi diantara komponen-komponen tersebut yang memperkenalkan suatu sistem yang akan dibangun. Untuk membuat website etraining peneliti membagi dua rancangan website yaitu halaman pengguna dan halaman admin. Halaman admin berfungsi sebagai tempat mengelola kegiatan e-training yang ada di halaman pengguna dan halaman pengguna merupakan pusat kegiatan e- training.

c) Pengembangan Website

Pada penelitian ini tahap implementasi dan evaluasi dilakukan untuk menguji coba kelayakan website e-training sebagai tahap implementasi dan proses revisi model sebagai tahap evaluasi.

d) Pelaksanaan

Pada tahap ini, telah ditentukan format content, clear information, serta alligment and feedback yang di sudah disesuaikan dengan kebutuhan SDM.

Dalam tahap ini juga ada beberapa fase yang meliputi :

1. Pre-reading worksheet

2. Pre-test assesment

3. Training and coaching

4. Post test project review

5. Rewarding and apreciation certification

e) Pelaporan Hasil

Setelah pelatihan atau e-training telah dilakukan, maka hasil yang di dapatkan dilaporkan sebagai bahan untuk pengevaluasian ke depan, sekaligus terkait dengan hal ini juga dapat disesuaikan dengan kriteria penilaian atau kriteria evaluasi dari e-training yang diharapkan, sehingga dapat dilihat persentase keberhasilan yang diperoleh dari e-training tersebut.

1) Melakukan Pelatihan Online atau E-Training Berbasis Pemanfaatan Platform Video Selain itu, dalam hal ini pula dapat memanfaatkan platform atau tools lain yang juga

disesuaikan dengan keterkaitan kebutuhan kegiatan pelatihan dengan kemampuan SDM dalam penggunaan platform atau tools tersebut.

2) Pendayagunaan Teknologi (Digitalization) bagi SDM

Dalam implementasinya, ada beberapa tahapan yang akan dilakukan terkait proses penerapan pendayagunaan teknologi di masa pandemi covid-19 dalam upaya meningkatkan keunggulan SDM, yaitu :

1. Persiapan Awal (Memunculkan Jiwa Inovasi SDM)

2. Pengimplementasian Teknologi/Digitalization dalam Sistem Kerja dan Komunikasi

3. Penciptaan Hasil dari Digitalization di Masa Pandemi

Dengan memanfaatkan kehadiran teknologi yang semakin canggih, maka di masa pandemi dapat menjadi kesempatan emas bagi SDM untuk upgrading digital skill mereka dengan melakukan transformasi pemanfaatan nilai-nilai teknologi yang ada untuk pelaksanaan sistem kerja yang lebih mudah dan efesien. 
3. Monitoring/Evaluasi Akhir

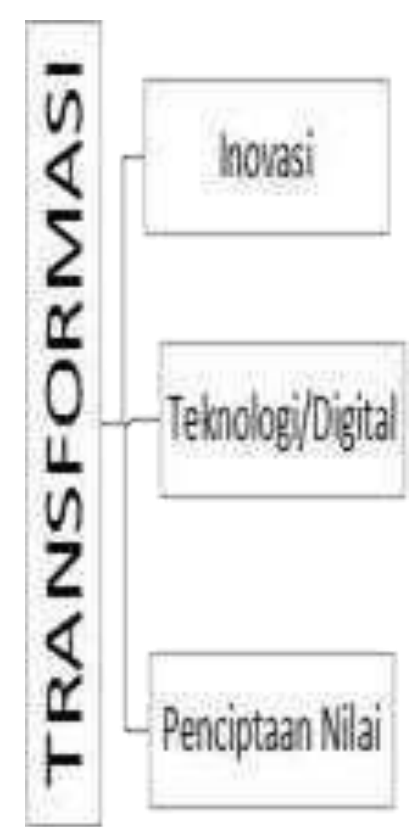

Gambar VI Tahapan Rencana Implementasi Digitalization SDM di Masa Pandemi

4. Penguatan Diri (Iman, Imun, dan Aman)

Dalam implementasinya, ada beberapa tahapan yang akan dilakukan terkait proses penerapan strategi penguatan dalam diri yang meliputi Iman, Imun, dan Aman dalam upaya meningkatkan keunggulan SDM di tengah masa pandemi covid-19, yaitu :

1. Kegiatan Spiritual Mentoring

Tahapan dalam implementasi penguatan iman melalui spiritual mentoring yaitu sebagai berikut:

a. Persiapan Awal

b. Pembentukan Kelompok Spiritual Mentoring dan Kebutuhan Pemateri Pekanan

c. Pelaksanaan

Pelaksanaan Spiritual Mentoring ini dilakukan virtual, melalui kajian-kajian dengan pemateri khusus dihadirkan yang dapat meningkatkan perasaan optimisme dan keyakinan pada hidup untuk tetap semangat, sehingga SDM dapat mampu terus bertahan meski di tengah kondisi atau situasi yang tidak diharapkan. Spiritual mentoring juga diharapkan dapat mempererat ikatan antar individu dalam sebuah organisasi atau perusahaan.

d. Pelaporan Hasil dan Evaluasi

2. Kegiatan Komunikasi Berkala

Tahapan dalam implementasi penguatan iman melalui spiritual mentoring yaitu sebagai berikut:
a. Persiapan Awal
b. Pembentukan Jadwal dan Sistem

Jadwal berkala untuk melakukan komunikasi baik antar departemen maupun atasan dengan SDM di bawahnya disesuaikan dengan kebutuhan, sehingga terbangun komitmen yang pasti, sekaligus penentuan sistem pelaksanaan dengan mengutamakan efisiensi dan efektivitas. C. Pelaksanaan

Komunikasi berkala dapat memanfaatkan berbagai tools atau media yang disepakati bersama, tentunya dengan melihat fitur yang memang sesuai yang dibutuhkan SDM dalam 
upaya kelancaran kegiatan. Komunikasi yang dilakukan pun lebih ke arah semi formal sehingga hubungan dan kehangatan antar individu dapat lebih terasa, kritik maupun saran juga dapat menjadi respons yang sangat bermanfaat bagi perkembangan SDM maupun organisasi atau perusahaan itu sendiri.

d. Pelaporan Hasil dan Evaluasi

2. Kegiatan Pemberian Fasilitas/Jaminan Kesehatan

Tahapan dalam implementasi penguatan iman melalui spiritual mentoring yaitu sebagai berikut :

a. Persiapan Awal/Analisis Kebutuhan

Kesehatan dapat mempengaruhi emosional seseorang. Untuk itu, sebagai seorang pemimpin yang peduli akan kesehatan harus menjamin kesehatan, keselamatan, dan kesejahteraan para karyawan agar dapat bekerja secara optimal. Terutama dengan adanya wabah covid-19 sorang pemimpin harus membuat kebijakan yang menjamin kesehatan karyawannya.

b. Perancangan Sistem

c. Pelaksanaan

Dalam hal ini, pemberian fasilitas kesehatan sebagai bentuk rasa aman bagi SDM di tengah Pandemi Covid-19 terutama bagi mereka yang masih tetap melakukan aktivitas melalui tatap muka, dapat dilakukan secara langsung dengan pemberian alat-alat kesehatan sebagai pelindung diri, sehingga dapat mengurangi kecemasan dalam diri SDM dan dapat melakukan kegiatan atau aktivitasnya dengan produktif. Sementara bagi SDM yang melakukan kegiatan atau aktivitas di rumah, atau adanya pengurangan aktivitas di dalam organisasi atau perusahaan, maka pemberian jaminan kesehatan dapat diupayakan melalui kontrol kesehatan atau cek kesehatan gratis secara berkala, sehingga pimpinan dapat terus memantau kesehatan dan keamanan dari seluruh SDM yang ada di organisasi atau perusahaannya.

Membuat kebijakan tantang jaminan alat perlindungan kesehatan dengan memberi masker, hand sanitizer, dan penyemprotan disinfektan di seluruh area perusahaan sebagai pencegahan penyebaran covid-19 dan untuk menjamin kesehatan serta kenyamanan para karyawan dalam bekerja. Dengan adanya alat perlindungan kesehatan dapat mengantisipasi kecemasan karyawan akibat virus Corona.

Perusahaan dapat memberikan pemeriksaan secara gratis seperti tes kesehatan dengan cara bekerjasama dengan suatu lembaga kesehatan. Dengan langkah ini diharapkan mampu mengetahui kondisi kesehatan karyawan dan mengantisipasi penularan virus Corona. Secara tidak langsung hal ini memberikan suatu kepuasan terhadap karyawan sehingga suasana hati dan emosional mereka lebih terkondisikan

d. Pelaporan Hasil dan Evaluasi

4. Motivasi (Kegiatan Sharing Session, dan Virtual Team Building)

Dalam implementasinya, ada beberapa tahapan yang akan dilakukan terkait proses penerapan kegiatan pemberian motivasi yaitu melalui sharing session atau sesi diskusi dan penguatan tim secara virtual dalam upaya meningkatkan keunggulan SDM di tengah masa pandemi covid-19, yaitu :

a. Persiapan Awal

b. Analisis Kebutuhan dan Tujuan 
c. Persiapan Program dan Tools

d. Pematangan Konsep

e. Pelaksanaan

1. Mendengarkan Aspirasi Karyawan

Mendengarkan aspirasi karyawan merupakan salah satu strategi pengembangan SDM yang sangat penting agar perusahaan dapat berkembang bersama - sama karyawan.

2. Reward \& Punishment Terhadap Karyawan

Reward atau apresiasi merupakan cara yang tepat untuk menunjukkan bahwa perusahaan sangat menghargai hasil kerja karyawan yang sangat baik untuk perkembangan atau kemajuan perusahaan. Sedangkan Punishment ini lebih ditujukan sebagai bentuk sanksi yang menyadarkan karyawan agar lebih berhati - hati dan disiplin dalam bekerja sehingga akan meminimalisir kesalahan yang sama akan terjadi.

\section{Kesimpulan}

kondisi Pandemi Covid-19 ini pun mereka tetap perlu untuk meningkatkan kualitas dan dapat unggul dalam berbagai kondisi serta situasi yang sulit dikendalikan. Beberapa strategi patut dilakukan sebagai upaya dalam rangka mendorong SDM tersebut agar tetap unggul serta produktif.

Melalui desain ulang pekerjaan (Job Redesign) bagi SDM dapat menjadi langkah awal agar pekerjaan disesuaikan dengan kondisi yang tengah dihadapi, SDM pada akhirnya mampu beradaptasi serta melakukan segala penyesuaian, selanjutnya dengan adanya pelatihan atau training online bagi SDM di tengah Pandemi Covid-19 dapat pula menjadi upaya untuk terus meningkatkan pengetahuan sekaligus skill sehingga individu dapat terus berkembang dan unggul, selain itu dengan pendayagunaan teknologi atau digitalization pula dapat menjadi strategi yang tepat untuk membantu SDM dalam upaya transformasi dan mengupgrade skill digitalnya yang perannya sangat mendominasi di era saat ini, maka dengan adanya hal-hal tersebut SDM yang ada dapat memiliki kemampuan untuk beradaptasi dan berpikir secara kritis sekaligus unggul dengan kemampuannya mengupgrade skill yang dimiliki. Di samping itu pula, penguatan diri bagi SDM turut mendorong kualitas, melalui strategi penguatan iman, imun, dan aman sekaligus adanya pemberian motivasi yang berkelanjutan dari pimpinan dan antar individu melalui sharing session menjadi salah satu strategi yang kuat dalam upaya pembentukan tim yang tangguh di masa Pandemi Covid-19 ini. 


\section{Bibliografi}

Appiah, K. A. (2010). The ethics of identity. Princeton University Press.

Colombo, E., \& Stanca, L. (2008). The impact of training on productivity: evidence from a large panel of firms.

Gomez-Mejia, L. R., Makri, M., \& Kintana, M. L. (2010). Diversification decisions in family-controlled firms. Journal of Management Studies, 47(2), 223-252.

Kim, Y., Williams, R., Rothwell, W. J., \& Penaloza, P. (2014). A strategic model for technical talent management: A model based on a qualitative case study. Performance Improvement Quarterly, 26(4), 93-121.

Makmur, M. T., \& Hadi, S. (2020). Strategi Pemulihan Perekonomian Terdampak Covid-19 Melalui Perencanaan Pembangunan Sumber Daya Manusia Unggul Berbasis Industri

4.0. Majalah Media Perencana, 1(1), 117-126.

Mindarti, S., Zalizar, L., Damat, E. A., \& Fajriani, S. (2020). Characterization of fiber fraction, physical and chemical properties of coffee flour (Coffea sp.) as functional foodstuff for diabetes mellitus patient. E\&ES, 462(1), 12017.

Mustari, M., \& Rahman, M. T. (2012). Pengantar Metode Penelitian. Laksbang Pressindo.

Prabawa, I. M. A., \& Supartha, I. W. G. (2018). Meningkatkan produktivitas karyawan melalui Pemberdayaan, kerja sama tim dan pelatihan Di perusahaan jasa. E-Jurnal Manajemen Universitas Udayana, 7(1).

Purnaya, I. G. K., \& SE, S. H. (2016). Manajemen Sumber Daya Manusia. Penerbit Andi. 
Rabbani, M., Maleknejad, K., \& Aghazadeh, N. (2007). Numerical computational solution of the Volterra integral equations system of the second kind by using an expansion method.Applied Mathematics and Computation, 187(2), 1143-1146.

Rahmasari, L. (2012). Pengaruh kecerdasan intelektual, kecerdasan emosi dan kecerdasan spiritual terhadap kinerja karyawan. Majalah Ilmiah Informatika, $3(1)$.

Rustam, M. H. D. C. (n.d.). Analisis Manajemen Program Pelatihan Karyawan Bank BRI Syariah Kantor Pusat Jakarta. Fakultas Ilmu Dakwah dan Ilmu Komunikasi Universitas Islam Negeri Syarif ....

Santika, I. G. N. N. (2020). Optimalisasi Peran Keluarga Dalam Menghadapi Persoalan Covid-19: Sebuah Kajian Literatur. Jurnal Ilmiah Ilmu Sosial, 6(2), 127-137.

Shopiana, S. (2020). Hubungan Konsep Diri Dan Komitmen Pada Tugas Dengan Motivasi Kerja Warga Belajar Lembaga Kursus Dan Pelatihan Shopy Kota Tanjung Balai. Universitas Islam Negeri Sumatera Utara.

Smale, A., Bagdadli, S., Cotton, R., Dello Russo, S., Dickmann, M., Dysvik, A., Gianecchini,M., Kaše, R., Lazarova, M., \& Reichel, A. (2019). Proactive career behaviors and

subjective career success: The moderating role of national culture. Journal of Organizational Behavior, 40(1), 105-122.

Sudaryo, Y., Aribowo, A., \& Sofiati, N. A. (2018). Manajemen Sumber Daya Manusia: Kompensasi Tidak Langsung dan Lingkungan Kerja Fisik. Penerbit Andi. 